Copyright (C) 2018 by Academic Publishing House Researcher

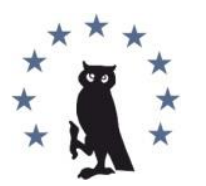

Published in the Russian Federation

European Researcher. Series A

Has been issued since 2010.

ISSN 2219-8229

E-ISSN 2224-0136

2018, 9(1): 24-33

DOI: 10.13187/er.2018.1.24

www.erjournal.ru

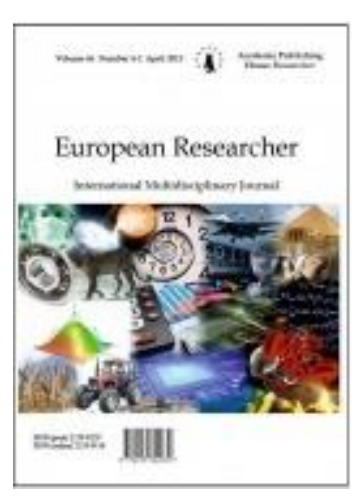

\title{
Curricular Transformation from the Perspective of the Trends in the Education of Pupils who are Deaf or Hard of Hearing in Czech Republic
}

\author{
Petra Kurková a, Dagmar Nemček b, Elena Bendíková c, * \\ a Palacký University Olomouc, Olomouc, Czech Republic \\ ${ }^{b}$ Comenius University in Bratislava, Bratislava, Slovakia \\ c Matej Bel University, Banská Bystrica, Slovakia
}

\begin{abstract}
The study deals with curricular transformation from the perspective of the trends in the education of pupils who are deaf or hard of hearing in Czech Republic after 1993. It compares educational approaches in primary education with an emphasis on regular and special education of pupils who are deaf or hard of hearing. After the adoption of the Education Act in 2004, the number of pupils in schools for the deaf or hard of hearing started to gradually decline and there have been demographic changes as to how and where pupils who are deaf or hard of hearing receive their education. Effective from September 2016, the amendment to the Education Act brought new education opportunities for pupils who are deaf or hard of hearing, which respect their language and cultural differences. However, all these changes - including support measures may not affect the successful integration of a pupil who is deaf or hard of hearing. The degree of disability of the pupil being integrated and the system of measures to support the individual's special needs in more challenging conditions also play an important role. The on-going curricular reform provides teachers with an opportunity to modify and expand the curriculum to support the development of pupils who are deaf or hard of hearing together with their peers and to form a solid foundation for their future lives.
\end{abstract}

Keywords: communication; special and mainstream education; legislation; statistical yearbook of education.

\section{Introduction}

The population of European Union countries is a diverse macrocosm. It consists of individuals from different ethnic, cultural and socio-economic backgrounds, yet most of them have one thing in common: they all can hear. These people represent the hearing world - they value their ability to hear and speak and the ease with which they can communicate with others. For most people, the idea of losing their hearing and not being able to enjoy music, films or live broadcasts is unimaginable. For the majority population, it is quite difficult to appreciate how people who are deaf or hard of hearing feel, or to imagine what life without auditory perception is like.

Living among this hearing majority population, there is the cultural and linguistic minority group comprising the deaf. It consists of people with varying degrees of hearing loss, including deafness, with different professions, ethnic backgrounds and socio-economic status. These people

\footnotetext{
${ }^{*}$ Corresponding author

E-mail addresses: elena.bendikova@umb.sk (E. Bendíková)
} 
see the Czech sign language as their language and share many cultural views that are valued and appreciated by all members of this group. Unlike the majority population, they do not perceive their hearing loss as a handicap, but rather as part of their unique identity.

\section{Objective}

The present study aims to describe the curricular transformation from the perspective of the trends in the education of pupils who are deaf or hard of hearing in the Czech Republic in a historical context in the period that followed the breakup of Czechoslovakia and during which the Czech and Slovak Republics emerged as independent states, i.e. since 1 January 1993.

\section{Methods}

We chose the content analysis of documents (Onwuegbuzie, Teddlie, 2003) as the main method of data acquisition. This is a qualitative method with the accent on an objective and systematic description of the content of documents focusing on curricular transformation from the perspective of the trends in the education of pupils who are deaf or hard of hearing. We used a multitude of available scientific, research and technical papers and data that are published on the Internet, including search databases (e.g. laws). Based on the data that were acquired through the content analysis of texts relating to curricular transformation from the perspective of the trends in the education of pupils who are deaf or hard of hearing, we subsequently applied comparative methods, abstraction, generalisation and other logic methods to generate new findings (Hendl, Remr, 2017).

\section{Results and Discussion}

\section{Historical context of the trends in education in Czechoslovakia}

The earliest references to the integrated education of people who are deaf or hard of hearing dates back to as early as 1881, when the Austrian Ministry of Education issued a decree on creating the conditions for teaching persons who are deaf or hard of hearing at regular schools due to the insufficient capacity of the then existing institutes for the deaf and dumb (Hrubý, 1999: 152). Founded in 1786, the Prague Institute for the Deaf and Dumb was the first institute of its kind. Teaching made use of the finger alphabet, signs and articulation and later also the sign language and the bilingual method. At the 1880 Milano Congress, a resolution on preference for the oral method was adopted which concerned the education of pupils who are deaf or hard of hearing in schools in Europe. At Czech schools, the then existing institutes for the deaf and dumb, this resolution started to be more widely applied in the period 1922-1924. As a result of strict oral education, the 'pure' sign language declined. These limitations in the education of people who are deaf or hard of hearing also affected education quality and opportunities. Even in the subsequent years, changes in school-related legislation had no practical impact on the education process for pupils who are deaf or hard of hearing, and - with few exceptions - the education was provided in special schools, i.e. in a segregated setting (Act No 29/1984 Sb.; Decree No 291/1991 Zb.).

\section{Legislative regulation of education of pupils who are deaf or hard of hearing in the Czech Republic}

Addressing social inequalities greatly improves health and well-being (Haegele, Sutherland, 2015; Kuenburg et al., 2016). The causes of inequality are complex, they are rooted in the very beginning of the life cycle and have an effect over its entire duration (Nielsen, Krasnik, 2010; Robertson et al., 2017; Smith et al., 2012; Ubido et al., 2002). People's disadvantages and vulnerabilities tend to deepen during their life and correlate with behaviours that have an important impact on health, such as high-risk and harmful alcohol abuse and smoking, poor eating habits, lack of physical activity and mental health problems. The above behaviours are largely the result of stress and other life difficulties (Ministry of Health of the Czech Republic, 2015).

According to Article 33 of the Charter of Fundamental Rights and Freedoms, education is a fundamental right of every person (Resolution No 2/1993 Sb., as amended by Act No 162/1998 $\mathrm{Sb}$.). School attendance is obligatory for a period specified by law. In the course of education, an individual acquires key competences for their life as well as basic knowledge and information that can then be actively developed and used. However, this process - including encouraging children 
to embrace physically active lifestyles - also needs to be promoted in families from an early age, because it plays a crucial role in developing positive, health-oriented lifelong habits (Badura et al., 2017; Ellis et al., 2014; Sigmund, Sigmundová, 2014).

In the Czech Republic, the education of people who are deaf or hard of hearing is currently legally regulated by Act No 561/2004 Sb. on preschool, primary, secondary, tertiary vocational and other education (the Education Act), as amended. In addition to addressing the general principles and objectives of education and describing education programmes and the education system, etc., Section 16 deals with support for the education of children, pupils and students with special educational needs, which also includes pupils who are deaf or hard of hearing. Under this Act, a pupil who is deaf or hard of hearing means "a person who, in order to fulfil their educational potential or exercise their rights on an equitable basis with others, requires the provision of support measures. Support measures mean the necessary adaptations of education and school services as appropriate to the health condition, the cultural environment or other living conditions of the child, pupil or student." According to Barvíková (2015, p. 11), a pupil who is deaf or hard of hearing "has been diagnosed by a specialist doctor with a conduction, perception or mixed-type impairment of a long-term, progressive or permanent nature".

In the education process, communication and its effectiveness are a key issue. Education is based on mutual communication and understanding. Section 16(7) of Act No 561/2004 Sb., (as amended) grants "deaf and deaf-blind children, pupils and students the right to free education by means of or through communication systems for deaf and deaf-blind people". It follows from the above that there are certain specific aspects in the education of pupils who are deaf or hard of hearing.

Effective from September 2016, the amendment to the Education Act brought new education opportunities for pupils who are deaf or hard of hearing, which respect their language and cultural differences. Pupils who cannot perceive speech through hearing and who use a communication system other than spoken language receive education in a communication system for the deaf that meets the needs of the pupil. Pupils who receive education in the Czech sign language also receive education in the written Czech language, which they learn through the methods used in teaching Czech as a foreign language.

If the pupil prefers to communicate in the Czech sign language and is educated in a class where this method of communication is not the means of communication shared by all participants in the education process, the school will provide education to the pupil using a Czech sign language interpreter or a speech-to-text-reporter for the deaf. A sign language interpreter must provide proof of education, or practical experience and education through which they acquired knowledge of the Czech sign language at native-speaker level, and demonstrate interpreting skills at a level that makes it possible to provide full education to an individual who is deaf or hard of hearing (Act No 561/2004 Sb.). The interpreter performs the precise translation of the content communicated between the participants in the communication system chosen by the pupil. It is used throughout the duration of the education and during events that are organised by the school. The interpreter's services may be used concurrently by multiple pupils. If the pupil prefers the spoken form of the Czech language supported by written text and receives education in a class where this approach is not the communication system that is shared by everyone, the school will provide education to the pupil using a speech-to-text-reporter for the deaf. The speech-to-text-reporter converts spoken language into written form in real time (Decree No 27/2016 Sb.; Act No 155/1998 Sb.).

\section{Regular versus special education}

In 2004, the Czech Republic became a member of the European Union and its education system started to change in order to ensure compliance with the requirements of European legislation. These changes were formulated in the National Programme for the Development of Education in the Czech Republic (2001) and legislatively enshrined in Act No 561/2004 Sb. on preschool, primary, secondary, tertiary vocational and other education, which came into force as of 1 January 2005 (the Education Act). In this period, new curriculum documents were created concerning the education of children, pupils and students aged 3 to 19 years. The on-going school reform - which is being implemented in primary education through the Framework Education Programme for Primary Education, including its current changes (FEP PE, 2017) - defines the specific objectives, forms, duration and compulsory content of education, including safety and 
health conditions. These are mandatory for the development of school education programmes and the evaluation of the learning outcomes of all pupils who are deaf or hard of hearing and who are integrated in ordinary schools. The education programme is adapted so that it focuses on the given individual and takes into account his or her abilities.

In the Czech Republic, educational care for pupils who are deaf or hard of hearing is provided by a system of schools and school facilities that are established separately for these pupils. Another option is education through (individual or group) integration in regular schools. Scheid (1995, p. 16) defines integration as "the social inclusion of the disabled in society with other individuals", in a manner that is adequate to their needs. Even though the term inclusive education is currently being used in connection with the integration of children and pupils into mainstream education, in practice the difference between the terms integration and inclusion is fuzzy and both terms may be perceived as synonyms (Průcha, 2002). In the Czech environment, the term inclusion is not very well established, both legislatively and professionally. Dinold and Válková (2003, p. 52) define inclusion as: "a process that is shaped by everyday life integration, education ... Inclusion is not a goal, but rather a way of socialisation, independent living, and is characterised by a number of options ranging from the most restrictive to the least restrictive environments." In line with the above definition, we perceive inclusion as the culmination of the integration process during which such conditions (in the broadest sense of the word) are created so as to make it is possible to integrate an individual who is deaf or hard of hearing, including their participation in the different activities. Therefore, in the present text we use the term integrated education as it reflects more accurately the actual situation in the Czech education system.

The choice of the education form is up to the pupil's parents and it will affect the pupil's entire life. A boarding school for pupils who are deaf or hard of hearing may be perceived as a confirmation of differentness, and, on the contrary, a regular school may be a demonstration of normality. However, the main problem that is associated with hearing loss still lies in the subsequent disruption of the development of communication abilities, which is also linked with limited possibilities of socialisation (Bartlett et al., 2008; Kuenburg et al., 2016; McKee et al., 2011). It is therefore necessary to take into account that - for pupils who are deaf or hard of hearing - it is also important to be in contact with pupils with the same disability in order to share the same life situation.

Under current legislation, the education of pupils who are deaf or hard of hearing takes place primarily in regular schools in the form of integration. The success of school integration is influenced by the following factors:

- Degree of hearing loss.

- Level of communication skills (especially competence in the Czech language, i.e. both its spoken and written form).

- Ability to use available technical aids.

- Level of mental abilities.

- Level of the pupil's social skills and experience.

- Personality traits.

- Family.

For a child who is deaf or hard of hearing, the decision on integration is made by the legal guardians in cooperation with a special-education centre and school management. Integration can take the form of individual integration or the establishment of special classes within regular schools. In the case of children with severe hearing loss or a combined disability, integration is difficult because they lack a crucial prerequisite for coping with standard teaching and socialisation - sufficiently developed oral speech. These pupils not only understand little, but also the content of their communication is difficult to understand for others, because their speech lacks substance and grammar. In this case, sign language competence does not make it easier to communicate in a regular environment and even the presence of an interpreter may not guarantee successful integration (Potměšilová, Potměšil, 2014). The integration of pupils who are hard of hearing is usually easier because their vocabulary is richer, their writing is better and they are better able to communicate and, by extension, to socialise (Scheetz, 2012; Vágnerová, 2014). Both pupils who prefer oral communication and pupils who communicate in the sign language can use an assistant teacher, a Czech sign language interpreter or a speech-to-text-reporter for the deaf. 
In each case, an education counselling centre will assess whether the number of hours of the recommended support measure matches the pupil's needs (Decree No 416/2017 Sb., amending Decree No 27/2016 Sb., on the education of pupils with special educational needs and gifted pupils, as amended by Decree No 270/2017 Sb.).

\section{Examples of integrating information on the deaf community into the curriculum in mainstream education \\ First stage (years 1 to 5) of primary schools}

- An introduction to issues relating to people who are deaf or hard of hearing, teachers of pupils who are deaf or hard of hearing, teachers who are deaf or hard of hearing, interpreters, historical developments and trends, important people who were/are deaf or hard of hearing.

- Communication systems - the sign language, visualiser, transliterator of spoken Czech, audiology, rehabilitation, speech therapy.

- Communication technology, compensation aids, accessibility.

- Introducing jobs and professions that are available to them, using good practice examples.

- Leisure activities, interest-based organisations, sports activities.

\section{Second stage (years 6 to 9) of primary schools}

- An introduction to issues relating to people who are deaf or hard of hearing.

- Services for these groups (a person who is deaf, hard of hearing, deafened, deaf-blind, with residual hearing, with a cochlear implant), how they can make a phone call, what interpretation looks like.

- Differences between them, such as a person who is deaf, blind, deaf-blind.

- Technology, websites, interesting projects.

- History, prominent figures, successful athletes, deaflympics, cultural events for the deaf.

If an education counselling centre finds the support measures to be inadequate, the pupil can be enrolled in a school for pupils who are deaf or hard of hearing. In justified cases, pupils with a different disadvantage may also be educated in schools that are established based on the type of disadvantage. Enrolment requires a written request by the pupil's legal guardian and a recommendation (including justification) by an education counselling centre. No fewer than 6 and no more than 14 pupils may receive education within a class, taking into account their age and special educational needs. If the number of pupils makes it difficult to fulfil their educational potential, no fewer than 4 and no more than 6 pupils receive education in the class (Decree No 27/2016 Sb.).

Education in primary schools is spread over nine years and is divided into the first stage (years 1 to 5) and the second stage (years 6 to 9). All primary schools for the deaf or hard of hearing take advantage of Section 46(3) of the Education Act, which makes it possible to extend school attendance to ten years, upon approval from the ministry. In such a case, the first stage comprises years 1 to 6 and the second stage comprises years 7 to 10. At present, pupils are educated in thirteen primary schools for the deaf or hard of hearing, of which seven are in Bohemia (České Budějovice, Hradec Králové, Liberec, Plzeň and three in Prague) and six in Moravia (Brno, Ivančice, Kyjov, Olomouc, Ostrava and Valašské Meziříčí).

The advantage of these schools is a good didactic quality of teaching, which is adequate to the pupils' abilities. Another advantage may also be the very good organisation of free time in these facilities, with an accent on the specific aspects of communication within this minority population (Kurková, Scheetz, 2016; Kurkováet al., 2010). The disadvantage of this type of education may be the boarding-school nature of education, which removes the child from the natural family environment from an early age, severs ties to the family, minimizes opportunities to gain common experience, and education is isolated from real life (Komorná, 2008; Scheetz, 2012; Vágnerová, 2014).

An analysis of available data shows that the number of pupils with disabilities in primary schools has declined over the past five years. The majority pupils with disabilities are boys. However, for pupils who are deaf or hard of hearing, there have been no major changes in recent years and their numbers remain almost constant, i.e. around 1.2 thousand (1.6\% of the total number of pupils with disabilities in primary schools) and the majority are boys (Watier, 2016). In terms of integrated and special education, the performance indicators that were reported for the 
school year 2011/2012 in the Statistical Yearbook of Education showed - for the first time - a decrease in the number of pupils who are deaf or hard of hearing in primary education in special classes (559) and an increase in the number of individually integrated pupils (582), Table 1 . In the school year 2016/2017, as many as 704 pupils were enrolled in individual integration, of which 271 with severe hearing loss, and 522 pupils were enrolled in special classes, of which 310 with severe hearing loss (MEYS, 2017). This growing trend demonstrates the efforts of interested professionals to promote the individual integration of pupils who are deaf or hard of hearing to the maximum extent possible.

Table 1. An overview of pupils who are deaf or hard of hearing in integrated and special education

\begin{tabular}{|l|l|l|l|}
\hline \multicolumn{1}{|c|}{ School year } & \multicolumn{1}{|c|}{$\begin{array}{c}\text { Pupils in special } \\
\text { classes }\end{array}$} & \multicolumn{1}{c|}{$\begin{array}{c}\text { Individually } \\
\text { integrated pupils }\end{array}$} & \multicolumn{1}{c|}{ Total } \\
\hline $2016 / 2017$ & $522(310)$ & $704(271)$ & $1226(581)$ \\
\hline $2015 / 2016$ & $553(324)$ & $705(263)$ & $1258(587)$ \\
\hline $2014 / 2015$ & $538(304)$ & $645(222)$ & $1183(526)$ \\
\hline $2013 / 2014$ & $523(314)$ & $597(215)$ & $1120(529)$ \\
\hline $2012 / 2013$ & $539(308)$ & $574(200)$ & $1113(508)$ \\
\hline $2011 / 2012$ & $559(308)$ & $582(206)$ & $1141(514)$ \\
\hline $2010 / 2011$ & $635(331)$ & $581(177)$ & $1216(508)$ \\
\hline $2009 / 2010$ & $680(408)$ & $575(131)$ & $1255(539)$ \\
\hline $2008 / 2009$ & $694(407)$ & $570(101)$ & $1264(508)$ \\
\hline $2007 / 2008$ & $708(395)$ & $563(29)$ & $1271(424)$ \\
\hline $2006 / 2007$ & $739(428)$ & $537(27)$ & $1276(455)$ \\
\hline
\end{tabular}

Note. Statistical Yearbooks of Education - performance indicators. Retrieved from

http://toiler.uiv.cz/rocenka/rocenka.asp

\section{Approaches to communication in the education of pupils who are deaf or hard of hearing}

For a deeper understanding of the issues presented, we provide an overview of possible communication systems from the perspective of the education process for pupils who are deaf or hard of hearing. In practice, the following approaches are the most common: oral, simultaneous, total and bilingual. All systems agree on the need for a mutually acceptable information code. The objective of oral, simultaneous and total communication is to create speech as a means of education and socialisation. The bilingual approach aims to achieve the development of language and thinking independently of the quality of speech (Krahulcová, 2014; Scheetz, 2012). However, when choosing an education system, it is necessary to consider all aspects of the actual systems and their benefits for the specific pupil.

\section{System of oral communication}

Oral (the oral method, oralism) and auditory-oral approaches are considered to be the oldest education methods - they were also dominant in the Czech lands where the oral method was recognised as the only way of teaching in institutions educating the deaf. Oral and auditory-oral approaches represent "a wide range of forms and methods of didactic communication aimed at acquiring spoken, phonic speech and the didactic content of the education programme" (Krahulcová, 2014: 39). It consists in giving priority to (residual) hearing and sight and, in extreme cases, completely excluding visual-motor means of communication. In current practice, the following types may be encountered (Krahulcová, 2014; Scheetz, 2012; Strnadová, 2001):

- Pure oral monolingual systems focusing on mastering the reception (auditory and visual) and expression of spoken language that do not use the visualisation of spoken language.

- Oral systems supplemented by visual-motor markers of the underlying words (e.g. fingerspelling, auxiliary articulation signs, the written form of the language, Cued Speech, etc.).

- Oral systems supplemented by non-word visual-motor markers (also the bimodal system) that use various gestures, signs and mimics to improve the accuracy of a statement made in spoken language. 
Prioritising the oral method should make it possible to actively master the relevant spoken language and improve the potential for the socialisation of people who are deaf or hard of hearing. Key components of the oral method include acquiring competence in spoken language, training in lip-reading, and developing the functional capabilities of residual hearing (Potměšil, 2015). In all cases, the construction of the language system is mainly based on visual perception (i.e. lipreading), auditory training and continuous speech therapy. Some oral approaches use other supporting measures, where the written form of language is mastered using the method of global reading, fingerspelling and natural gestures (Strnadová, 2001).

Oral and auditory-oral approaches are supported by the results that have been achieved in a part of the population of people who are deaf or hard of hearing. However, the blanket implementation of the oral approach to the education of pupils who are deaf or hard of hearing cannot be recommended, because it does not respect the individual needs and abilities of individual pupils. An oral system without the use of manual means of communication then significantly reduces the options for receiving information, as it only allows the auditory method paired with lip-reading. The oral approach can benefit pupils who are hard of hearing and whose residual hearing can be effectively used. This concept is currently also supported by the advancement of digital prosthetic devices and neural prostheses, which improve auditory feedback in a portion of persons who are deaf or hard of hearing (Krahulcová, 2014).

\section{System of simultaneous communication}

Simultaneous communication (a bimodal model of education) is "such a system of information transmission in which spoken (oral, auditory, majority) language is dominant (main, leading) and is simultaneously supported by auxiliary means of communication that are aimed at visualising and grammatically refining the statement." (Krahulcová, 2014: 42). Forms of simultaneous communication may be the Czech sign language, fingerspelling, auxiliary articulation signs, the written form of the language, gestures, mimics, pantomime. The suitability of these systems has been demonstrated in children with severe hearing loss in families in which communication does not take place in the majority language, and in children whose parents try to learn the sign language. For education in schools, this method is only partially suitable, because simultaneous communication in spoken language and sign language is linguistically inconsistent. Moreover, the long-term production of two different communication codes leads to cognitive overload (Hrubý, 1999; Krahulcová, 2014; Scheetz, 2012).

\section{System of total communication}

Total (global, holistic) communication represents the philosophy of a certain way of thinking or communicating, rather than a communication or teaching method. It is about recognising the fact that not all communication methods are suitable for a given individual in all situations. That is why it is necessary to choose those means that are best suited to the individual in the given circumstances. It is officially defined as "a philosophy that brings together appropriate aural, manual and oral modes of communication in order to insure effective communication with and among the deaf and hard of hearing" (Evans, 2001: 13).

Total communication is based on the right of the deaf to optimal and unrestricted development in their native language. Optimal communication also prevents specific deviations in mental development. A child who does not hear should not be forced to adapt to the hearing world, but rather their differentness should be respected and, in its presence, all available methods and auxiliary means of communication should be used. Total communication includes all aural, manual and oral means of communication that can be used to achieve effective communication with persons who are deaf or hard of hearing (Horáková, 2012). The basis includes spoken language, spelling, signing and written language. Some components may be used separately (spoken language, signed Czech language, sign language), others are used mainly as auxiliary means (fingerspelling, mimics, pantomime, etc.). For the deaf, the most important means of communication is the sign language, but they use lip-reading when interacting with hearing people. When a hearing person communicates with a deaf person, clear articulation will be the most important, along with some of the auxiliary means (e.g. mimics, pantomime). If the hearing person knows signs, they can use them to supplement spoken language (the signed Czech language). 


\section{System of bilingual communication}

Bilingual communication is "the transmission of information in two language codes, in the sign language of the deaf and through speaking (the oral, majority, national language) among the deaf and between deaf people and hearing people" (Krahulcová, 2014: 50). These codes are not used simultaneously. This involves the full use of the native language of people with profound hearing loss (the Czech sign language) and the language of the majority society (the Czech language). A deaf teacher plays a key role in developing language and thinking. The teaching content is delivered to pupils by the deaf teacher in the sign language, and the information is then transformed by a hearing teacher into the written Czech language (Krahulcová, 2014). When teaching in the national sign language, it is not possible to simultaneously speak (Hrubý, 1999). Each of the two languages (spoken language and sign language) is taught separately. Pupils should be able to translate from spoken language to sign language and vice versa. The sign language is the first language to be acquired by children who are deaf or hard of hearing.

Regardless of whether pupils who are deaf or hard of hearing are enrolled in regular schools or whether they attend a school for the deaf and hard of hearing, complex communication is a necessary prerequisite for successfully fulfilling their academic requirements and for their full integration into the class of their peers. Targeted support for communication and mutual collaboration within a class or a school may alleviate or completely eliminate any potential feelings of social exclusion that people who are deaf or hard of hearing may have. However, communication deficiencies may cause pupils with varying degrees of hearing loss to inadequately develop their verbal or sign language vocabulary. As a result, these pupils do not have enough opportunities to engage in social interaction with their peers during the day.

\section{Conclusion}

After the adoption of the Education Act in 2004, the number of pupils in schools for the deaf and hard of hearing started to gradually decline and there have been demographic changes as to how and where pupils who are deaf or hard of hearing receive their education. Effective from September 2016, the amendment to the Education Act brought new education opportunities for pupils who are deaf or hard of hearing, which respect their language and cultural differences. Pupils who cannot perceive speech through hearing and who use a communication system other than spoken language receive education in a communication system for the deaf that meets the needs of the pupil. Pupils who receive education in the Czech sign language also receive education in the written Czech language, which they learn through the methods used in teaching Czech as a foreign language.

However, all these changes - including support measures - may not affect the successful integration of a pupil who is deaf or hard of hearing. The degree of disability of the pupil being integrated and the system of measures to support the individual's special needs in more challenging conditions also play an important role.

The on-going curricular reform provides teachers with an opportunity to modify and expand the curriculum to support the development of pupils who are deaf or hard of hearing together with their peers and to form a solid foundation for their future lives.

\section{Acknowledgments}

The scientific paper was supported by grant projects VEGA No. 1/0242/17 and VEGA No. 1/0726/17.

\section{References}

Badura et al., 2017 - Badura, P., Madarasova Geckova, A., Sigmundova, D., Sigmund, E., van Dijk, J. P., Reijneveld, S. A. (2017). Do family environment factors play a role in adolescents' involvement in organized activities? Journal of Adolescence, 59, 59-66. doi: 10.1016/j.adolescence.2017.05.017.

Bartlett et al., 2008 - Bartlett, G., Blais, R., Tamblyn, R., Clermont, R. J., \& MacGibbon, B. (2008). Impact of patient communication problems on the risk of preventable adverse events in acute care settings. Canadian Medical Association Journal, 178, 1555-1562. doi:10.1503/cmaj.07069o 
Barvíková, 2015 - Barvíková, J. (2015). Katalog podpůrných opatření pro žáky s potřebou podpory ve vzdělávání z důvodu sluchového postižení nebo oslabení sluchového vnímání [Catalogue of support measures for pupils who require support in education due to hearing impairment]. Olomouc, Czech Republic: Palacký University Olomouc.

Czech National Council, 1993 - Czech National Council (1993). Charter of Fundamental Rights and Freedoms of 16 December 1992, No 2/1993 Sb. Retrieved from: http://portal.gov.cz/app/zakony/zakonPar.jsp?page $=$ o\&idBiblio $=40453 \& n r=2 \sim 2$ F1993\&rpp $=50 \#$ local-content

Dinold, Válková, 2003 - Dinold, M., Válková, H. (2003). Inclusion in physical education in schools. In H. van Coppenolle, J. C. De Potter, A. Van Peteghem, S. Djobova, \& K. Wijns, K. (Eds.), Inclusion and integration through Adapted Physical Activity (pp. 51-76). Leuven, Belgium: THENAPA.

Ellis et al., 2014 - Ellis, M. K., Lieberman, L. J., Dummer, G. M. (2014). Parent influences on physical activity participation and physical fitness of deaf children. Journal of Deaf Studies and Deaf Education, 19(2), 270-81. doi: 10.1093/deafed/ento33

Evans, 2001 - Evans, L. (2001). Totální komunikace, struktura a strategie [Total communication, structure and strategy]. Hradec Králové, Czech Republic: Pedagogické centrum.

Haegele, Sutherland, 2015 - Haegele, J. A., Sutherland, S. (2015). Perspectives of students with disabilities toward physical education: A qualitative inquiry review. Quest, 67(3), 255-273. doi: 10.1080/00336297.2015.1050118

Hendl, Remr, 2017 - Hendl, J., Remr, J. (2017). Metody výzkumu a evaluace [Methods of research and evaluation]. Prague, Czech Republic: Portál.

Horáková, 2012 - Horáková, R. (2012). Sluchové postižení: úvod do surdopedie [Hearing impairment: an introduction to surdopedy]. Prague, Czech Republic: Portál.

Hrubý, 1999 - Hrubý, J. (1999). Velký ilustrovaný průvodce neslyšících a nedoslýchavých po jejich vlastním osudu [Great illustrated guidebook for deaf and hard-of-hearing people after their own fate] (Vol. 2, $2^{\text {nd }}$ ed.). Prague, Czech Republic: Septima \& FRPSP.

Komorná, 2008 - Komorná, $M$. (2008). Systém vzdělávání osob se sluchovým postižením v ČR a specifika vzdělávacích metod při výuce [The system for educating people who are deaf or hard of hearing in the Czech Republic and the specifics of educational methods in teaching] (2 ${ }^{\text {nd }}$ rev. ed.). Prague, Czech Republic: Czech Chamber of Sign Language Interpreters.

Krahulcová, 2014 - Krahulcová, B. (2014). Komunikační systémy sluchově postižených [Communication systems for the deaf and hard of hearing]. Prague, Czech Republic: Beakra.

Kuenburg, 2016 - Kuenburg, A., Fellinger, P., Fellinger, J. (2016). Health care access among deaf people. Journal of Deaf Studies and Deaf Education, 21(1), 1-10. doi: 10.1093/deafed/envo42

Kurková, Scheetz, 2016 - Kurková, P., Scheetz, N.A. (2016). Communication Strategies Used by Physical Education Teachers and Coaches in Residential Schools for the Deaf in the U.S. Acta Facultatis Educationis Physicae Universitatis Comenianae, 56(1), 1-16. doi: 10.1515/afepuc-20160001

Kurková et al., 2010 - Kurková, P., Scheetz, N. A., Stelzer, J. (2010). Health and physical education as an important part of school curricula: A comparison of schools for the deaf in the Czech Republic and the United States. American Annals of the Deaf, 155(1), 78-95.

McKee, 2011 - McKee, M.M., Barnett, S.L., Block, R.C., Pearson, T.A. (2011). Impact of communication on preventive services among deaf American Sign Language users. American Journal of Preventive Medicine, 41, 75-79. doi:10.1016/j.amepre.2011.03.004

Ministry of Health... - Ministry of Health of the Czech Republic. (2015). Health 2020 National Strategy for Health Protection and Promotion and Disease Prevention. Action plan 1: Promotion of physical activity for the period 2015-2020. Retrieved from: http://www.mzcr.cz/Admin/_upload/ files/5/akční\%2oplány\%20\%20př́lohy/AP\%2001\%20podpora\%2opohybové\%20aktivity.pdf

National Programme... - National Programme for the Development of Education in the Czech Republic (2001). Retrieved from Ministry of Education, Youth, and Sports [Czech Republic] website: http://www.msmt.cz/dokumenty/bila-kniha-narodni-program-rozvoje-vzdelavani-vceske-republice-formuje-vladni-strategii-v-oblasti-vzdelavani-strategie-odrazi-celospolecenskezajmy-a-dava-konkretni-podnety-k-praci-skol 
Nielsen, Krasnik, 2010 - Nielsen, S. S., Krasnik, A. (2010). Poorer self-perceived health among migrants and ethnic minorities versus the majority population in Europe: A systematic review. International Journal of Public Health, 55, 357-371. doi:10.1007/s0oo38-010-0145-4

Onwuegbuzie, Teddlie, 2003 - Onwuegbuzie, A. J., Teddlie, C. (2003). A framework for analyzing data in mixed methods research. In A. Tashakkori \& C. Teddlie (Eds.), Handbook of mixed methods in social and behavioral research (pp. 351-383). Thousand Oaks, Ca: Sage Publications.

Potměšil, 2015 - Potměšil, M. (2015). Osobnost dítěte v kontextu vady sluchu. [A child’s personality in the context of hearing impairment] Olomouc, Czech Republic: Palacký University Olomouc.

Potměšilová, Potměšil, 2014 - Potměšilová, P., Potměšil, M. (2014). Pedagogický pracovník v integrovaném vzdělávání a integrované výchově [A teacher in integrated education and care]. Sociální pedagogika, 2(2), 88-101. doi: 10.7441/soced.2014.02.02.06

Průcha, 2002 - Průcha, J. (2002) Moderní pedagogika [Modern pedagogy]. Prague, Czech Republic: Portál.

Framework Education... - Framework Education Programme for Primary Education. (2017). Prague, Czech Republic: Ministry of Education, Youth and Sports.

Robertson et al., 2017 - Robertson, P.M., McFarland, L.A., Sciuchetti, M.B., García, S.B. (2017). Connecting the dots: An exploration of how pre-service special education teachers make sense of disability and diversity. Teaching and Teacher Education, 65, 34-47. doi: 10.1016/j.tate.2017.02.020

Scheetz, 2012 - Scheetz, N.A. (2012). Deaf education in the 21st century: Topics and trends. Boston, MA: Pearson.

Scheid, 1995 - Scheid, V. (1995). Chancen der Integration durch Sport: Behinderten machen Sport (Vol 2). Aachen, Germany: Meyer \& Meyer.

Sigmund, Sigmundova, 2014 - Sigmund, E., Sigmundova, D. (2014). School-related physical activity, lifestyle and obesity in children. Olomouc, Czech Republic: Palacký University Olomouc.

Smith et al., 2012 - Smith, C.E., Massey-Stokes, M., Lieberth, A. (2012). Health information needs of d/Deaf adolescent females: A call to action. American Annals of the Deaf, 157, 41-47. doi:10.1353/aad.2012.1608

Strnadová, 2001 - Strnadová, $V$. (2001). Hádej, co ř́kám, aneb odezírání je nejisté umění [Guess what I am saying or lip-reading is an uncertain discipline] ( $2^{\text {nd }} \mathrm{rev}$. ed.). Prague, Czech Republic: ASNEP.

Ubido et al., 2002 - Ubido, J., Huntington, J., Warburton, D. (2002). Inequalities in access to healthcare faced by women who are deaf. Health \& Social Care in the Community, 10, 247-253. doi:10.1046/j.1365-2524.2002.00365.

Constitutional Act... - Constitutional Act amending the Charter of Fundamental Rights and Freedoms of 12 June 1998, No 162/1998 Sb.

Vágnerová, 2014 - Vágnerová, M. (2014). Současná psychopatologie pro pomáhající profese [Contemporary psychopathology for assisting professions]. Prague, Czech Republic: Portál.

Decree No 27/2016 Sb. - Decree No 27/2016 Sb., on the education of pupils with special educational needs and gifted pupils.

Decree No 291/1991 Zb. - Decree No 291/1991 Zb., Decree of the Ministry of Education, Youth and Sports of the Czech Republic on Primary Schools

Decree No 416/2017 Sb. - Decree No 416/2017 Sb., amending Decree No 27/2016 Sb., on the education of pupils with special educational needs and gifted pupils, as amended by Decree No 270/2017 Sb.

Watier, 2016 - Watier, L. (2016). Ubylo žáků se zdravotním postižením [There are fewer pupils with disabilities]. Statistika \& my, 6(5), 28-29.

Act No 29/1984 Sb. - Act No 29/1984 Sb., on the system of primary and secondary schools (the Education Act)

Act No 155/1998 Sb. - Act No 155/1998 Sb., on communication systems for deaf and deafblind persons, as amended.

Act No 561/2004 Sb. - Act No 561/2004 Sb., on preschool, primary, secondary, tertiary vocational and other education (the Education Act). 